\title{
LAW WITHOUT NATIONS?
}


This page intentionally left blank 


\section{LAW WITHOUT NATIONS?}

Why Constitutional Government Requires Sovereign States

Jeremy A. Rabkin

PRINCETON U N IVERS I T Y PRES

PRINCETON A N D OXFOR D 
Copyright (C) 2005 by Princeton University Press

Published by Princeton University Press, 41 William Street, Princeton, New Jersey 08540

In the United Kingdom: Princeton University Press, 3 Market Place, Woodstock, Oxfordshire OX20 1SY

All Rights Reserved

Second printing, and first paperback printing, 2007

Paperback ISBN-13: 978-0-691-13055-2

Paperback ISBN-10: 0-691-13055-8

The Library of Congress has cataloged the cloth edition of this book as follows

Rabkin, Jeremy A.

Law without nations? : why constitutional government requires sovereign states / Jeremy A. Rabkin.

p. $\mathrm{cm}$.

Includes bibliographical references and index.

ISBN 0-691-09530-2 (cloth : alk. paper)

1. Sovereignty. 2. Constitutional law. 3. Globalization. 4. United States-Foreign relations-Europe. 5. Europe-Foreign relations-United States. I. Title.

KZ4041.R328 2005

$341.26-\mathrm{dc} 22 \quad 2004046638$

British Library Cataloging-in-Publication Data is available

This book has been composed in Sabon

Printed on acid-free paper. $\infty$

press.princeton.edu

Printed in the United States of America

$\begin{array}{lllllllll}10 & 9 & 8 & 7 & 6 & 5 & 4 & 3 & 2\end{array}$ 